1. I am age 18 or older, I have read and understood the above information and I wish to participate in the research and continue with the survey. *

Please read the statement carefully and only answer "yes" if you agree to all of the above. Your participation in this research is voluntary. You may discontinue participation at any time during the research activity. Your decision regarding whether or not to participate in this study will not result in any loss of benefits to which you are otherwise entitled.

\title{
Mark only one oval.
}

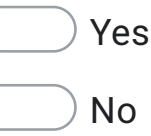

Educational background

2. What is the highest level of formal education that you have completed until now?

\section{Mark only one oval.}

High school diploma or GED

Some college

$\longrightarrow$ Associate and/or bachelor's degree

Bachelor's degree

Master's and/or professional degree

Doctorate

$\longrightarrow$ Prefer not to say

3. How many courses did you take in which you had to implement source code prior to participating in Girls Coding Day? *

If you do not remember a concrete number please provide an estimate. 
4. How do you estimate your computer coding experience before GCD? Mark only one oval.

$\begin{array}{lllll}1 & 2 & 3 & 4 & 5\end{array}$

5. How do you estimate your computer coding skills compared to the other members in your mentor group at Girls Coding Day?

Mark only one oval.

$\begin{array}{lllll}1 & 2 & 3 & 4 & 5\end{array}$

None $\square \longrightarrow \longrightarrow$ Highly skilled

6. How experienced were you using the following programming languages before attending Girls Coding Day?

Mark only one oval per row.

Very
inexperienced

7. If you are comfortable using any other programming language(s), please state them here. 
8. Are you currently working for a company? *

\section{Mark only one oval.}

$\square$ Yes $\quad$ Skip to question 9
No $\quad$ Skip to question 12

Your current company

9. What is your company's realm?

Check all that apply.

$\square$ Internet

$\square$ Education

$\square$ Finance

$\square$ Culture/Communication

Other:

10. What is your role in your company?

Check all that apply.

Software Engineer

Marketing

Different IT related role

Other:

11. How many years have you been working in this company before you participated in Girls Coding Day? 
Handout

The following questions are about the handout that was sent to you prior to Girls Coding Day. Please note that this research is independent of the Coding Girls' Club organization. NONE OF THE HANDOUT DESIGNERS WILL EVER SEE YOUR INDIVIDUAL ANSWERS.

12. Please indicate your level of agreement with the following statements related to your PERCEPTION of the handout.

Mark only one oval per row.

\begin{tabular}{|c|c|c|c|c|c|}
\hline & $\begin{array}{l}\text { Strongly } \\
\text { disagree }\end{array}$ & $\begin{array}{l}\text { Somewhat } \\
\text { disagree }\end{array}$ & $\begin{array}{c}\text { Neither agree } \\
\text { or disagree }\end{array}$ & $\begin{array}{l}\text { Somewhat } \\
\text { agree }\end{array}$ & $\begin{array}{c}\text { Strongly } \\
\text { agree }\end{array}$ \\
\hline $\begin{array}{l}\text { I am satisfied with the } \\
\text { handout. }\end{array}$ & & & & & \\
\hline
\end{tabular}

My expectations towards content of the handout were met.
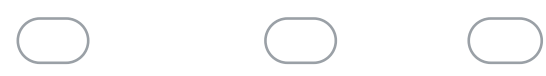

Installing the software required for $\mathrm{GCD}$ was easy based on the handout.

Overall, it was easy to understand the handout. 
13. Please indicate your level of agreement with the following statements related to your perception about the USEFULNESS of the handout.

Mark only one oval per row.

$\begin{array}{lcccc}\text { Strongly } & \text { Somewhat } & \text { Neither agree } & \text { Somewhat } & \text { Strongly } \\ \text { disagree } & \text { disagree } & \text { or disagree } & \text { agree } & \text { agree }\end{array}$

The handout improved my productivity during GCD.
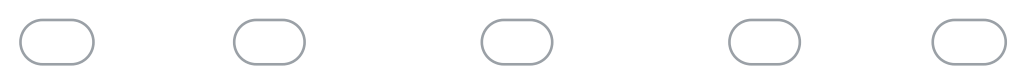

The handout improved my effectiveness during GCD.
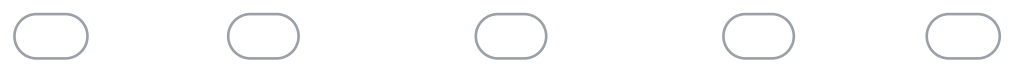

Overall, the handout was useful during GCD.

14. In your opinion, what was good about the handout you received prior to Girls Coding Day?

15. What could be improved about the handout you received prior to GCD?

Mentoring

The following questions are about your mentoring experience during Girls Coding Day. Please note that this research is independent of the Coding Girls' Club organization. experience NONE OF THE MENTORS WILL EVER SEE YOUR INDIVIDUAL ANSWERS. 
16. Please indicate your level of agreement with the following statements related to your IMPRESSION of your mentoring experience.

Mark only one oval per row.

\begin{tabular}{|c|c|c|c|c|c|}
\hline & $\begin{array}{l}\text { Strongly } \\
\text { disagree }\end{array}$ & $\begin{array}{l}\text { Somewhat } \\
\text { disagree }\end{array}$ & $\begin{array}{c}\text { Neither agree } \\
\text { or disagree }\end{array}$ & $\begin{array}{c}\text { Somewhat } \\
\text { agree }\end{array}$ & $\begin{array}{c}\text { Strongly } \\
\text { agree }\end{array}$ \\
\hline $\begin{array}{l}\text { The mentor and } \\
\text { students ratio was } \\
\text { sufficient. }\end{array}$ & & & & & \\
\hline $\begin{array}{l}\text { I was unsure whether I } \\
\text { could ask my mentor } \\
\text { for feedback when I } \\
\text { needed it. }\end{array}$ & & & & & \\
\hline
\end{tabular}

My mentor solved my technical problems when they came up.
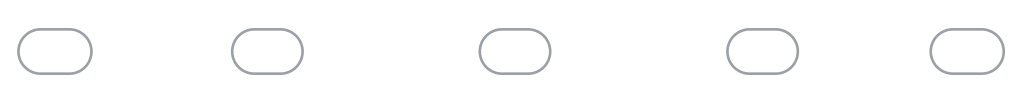

My mentor guided me to find solutions for my technical problems myself.

My mentor displayed patience.

My mentor answered my question in a clear way so that I could understand her/him easily. 
17. Please indicate your level of agreement with the following statements related to the SUPPORT you got from your mentoring experience.

Mark only one oval per row.

$\begin{gathered}\text { Strongly } \\ \text { disagree }\end{gathered}$ disagree
Having a mentor helped
me learn new technical
skills.
Having a mentor
provided me
opportunities to
learn/improve my
knowledge on different
technologies
Overall, having a mentor
was effective for
improving my technical
skills


18. Please indicate your level of agreement with the following statements about your SATISFACTION towards your mentoring experience.

Mark only one oval per row.

\begin{tabular}{ccccc} 
Strongly & Somewhat & Neither agree & Somewhat & Strongly \\
disagree & disagree & or disagree & agree & agree \\
\hline
\end{tabular}

I am satisfied with my mentoring experience.

Having a mentor helped me recognize my personal strengths
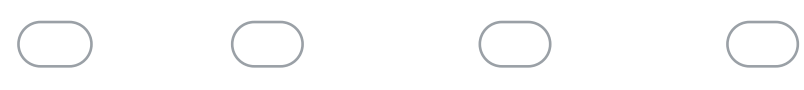
using technology.

Having a mentor helped me become more confident in learning
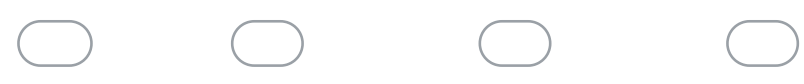
new technologies.

Having a mentor encouraged me to pursue programming

My expectations towards my mentoring experience were met.
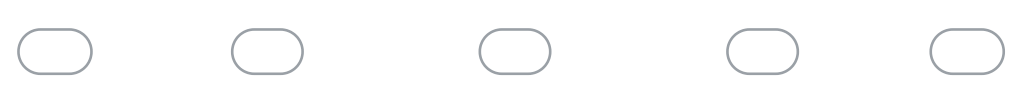

19. In your opinion, what was good about your mentoring experience?

20. How could your mentoring experience be improved?

\section{Kick-off party}


21. Please indicate your level of agreement with the following statements related to your perception of the USEFULNESS of the kick-off party.

Mark only one oval per row.

$\begin{gathered}\text { Strongly } \\ \text { disagree }\end{gathered}$ Somewhat Neither agree
disagree
The kick-off party
improved my
productivity during
GCD.
The kick-off party
improved my
effectiveness during
GCD.
Overall, the kick-off
party was useful as a
preparation for GCD.

22. Please indicate your level of agreement with the following statements related to your SATISFACTION with the kick-off party.

Mark only one oval per row.

\begin{tabular}{l} 
Strongly $\begin{array}{c}\text { Somewhat } \\
\text { disagree } \\
\text { disagree }\end{array}$ \\
\hline I am satisfied with the \\
kick-off party.
\end{tabular}

My ideal outcome towards the kick-off party was achieved.

My expectations towards the kick-off party were met. 
23. In your opinion, what was good about the kick-off party?

24. What could be improved about the kick-off party?

\section{Before Girls Coding Day}

25. To what extent was your participation in Girls Coding Day motivated by: Mark only one oval per row.

Wanting to have fun
Wanting to try out
Wamputer coding
Wechnologies
Weople
Wanting to meet new
experiences with others
Wanting to see what
others are working on
Wanting to do better in
wareer
wanool


26. If your decision to participate in Girls Coding Day was motivated by any other means than the ones mentioned before, please enter them here.

27. What prevented you to engage in computer coding prior to Girls Coding Day? (if anything)

During Girls Coding Day 
28. Which Girls Coding Day event did you attend *

\section{Mark only one oval.}

2018/11/2 Hong Kong Baptist University

2018/11/2 Xi'an University of Posts and Telecommunications (西安邮电大学)

2018/11/2 Beijing Language and Culture University (北京语言大学)

$\longrightarrow$ 2018/11/2 Sichuan International Studies University (四川外国语大学)

2018/11/2 Guangdong University of Foreign Studies (广东外语外贸大学)

2018/11/2 Central China Normal University (华中师范大学)

2018/11/2 Beijing Information Science \& Technology University (北京信息科技大学)

2018/11/2 Minjiang University (闽江学院)

2018/11/2 Nanjing University (南京大学)

2018/11/2 Renmin University of China Suzhou Campus (中国人民大学苏州校区)

2018/11/2 Renmin University of China (中国人民大学)

2018/11/2 Peking University (北京大学)

2018/11/2 Zhejiang University (浙江大学)

2018/11/2 Chongqing University (重庆大学)

2018/11/2 Communication University of China (中国传媒大学)

2018/11/2 Chengdu University of Information Technology (成都信息工程大学)

2018/11/2 Hainan University (海南大学)

2017/7/1 Wuhan

2017/7/22 Shanghai

2017/8/27 Guangzhou

2017/9/17 Hangzhou

2019/10/29 Chengdu

2017/11/26 Beijing

2017/12/2 Beijing

2017/12/16 Shenzhen

2018/11/24 Dalian

2018/3/25 Wuhan

2018/3/31 Nanjing

2018/11/24 Chengdu 
2018/11/24 Guangzhou

2018/12/23 Chongqing

2019/9/8 Beijing

29. If applicable, please provide the URL to any project you worked on during GCD (optional). We will use your project URL as an additional indicator of proficiency and will never make it public.

30. Please indicate your level of agreement with the following statements about your SATISFACTION WITH WHAT YOU LEARNED.

Mark only one oval per row.

$\begin{gathered}\text { Strongly } \\ \text { disagree }\end{gathered}$
$\begin{aligned} & \text { Lemewhat } \\ & \text { disagree } \\ & \text { a website was easy. }\end{aligned}$
$\begin{aligned} & \text { Overall, it was easy to } \\ & \text { build a website. }\end{aligned}$

I was satisfied with the website I built. 
31. Please indicate your level of agreement with the following statements about your SATISFACTION WITH THE OUTCOME you achieved.

Mark only one oval per row.

\begin{tabular}{|c|c|c|c|c|}
\hline $\begin{array}{l}\text { Strongly } \\
\text { disagree }\end{array}$ & $\begin{array}{c}\text { Somewhat } \\
\text { disagree }\end{array}$ & $\begin{array}{c}\text { Neither } \\
\text { disagree or } \\
\text { aqree }\end{array}$ & $\begin{array}{c}\text { Somewhat } \\
\text { agree }\end{array}$ & $\begin{array}{c}\text { Strongly } \\
\text { agree }\end{array}$ \\
\hline
\end{tabular}

I built the website I wanted to build.
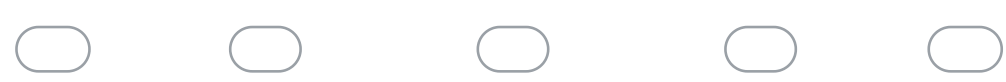

My expectations towards my website were satisfied.
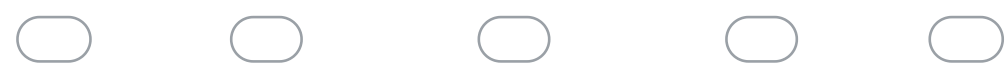

I am satisfied with the website I built.

32. Please indicate your level of agreement with the following statements related to your GROUP MEMBERS.

Mark only one oval per row.

$\begin{array}{ccccc}\text { Strongly } & \text { Somewhat } \\ \text { disagree } & \begin{array}{c}\text { Neither } \\ \text { disagree } \\ \text { agree }\end{array} & \begin{array}{c}\text { Somewhat } \\ \text { agree }\end{array} & \begin{array}{c}\text { Strongly } \\ \text { agree }\end{array}\end{array}$

Everyone had a chance to express her opinion.

Everyone had a chance to ask questions.
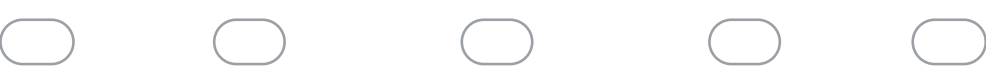

The group members participated very actively during the project.

Overall, the participation of each member in the project was effective. 
33. Please indicate your level of agreement with the following statements about your INTERACTION WITH OTHER PARTICIPANTS outside of your group.

Mark only one oval per row.

$\begin{gathered}\text { Strongly } \\ \text { disagree }\end{gathered}$ disagree
I was unsure if I could
ask other participants
for help
I helped other
participants if they
asked me for help
Other participants
helped me if I asked
them for help
The organizers
encouraged
participants to help
each other
My mentor encouraged
me to help other
participants

\section{After Girls Coding Day}


34. Please indicate your level of agreement with the following statements related to your LEVEL OF COMFORT using the following technologies after Girls Coding Day.

Mark only one oval per row.

$\begin{gathered}\text { Strongly } \\ \text { disagree }\end{gathered} \begin{gathered}\text { Somewhat } \\ \text { disagree }\end{gathered}$
I am comfortable with
writing programs in
HTML.
I am comfortable with
writing programs in
CSS.
I am comfortable with
writing programs in
PYTHON.
I am comfortable with
using GitHub.


35. Please indicate your level of agreement with the following statements related to your COMPUTER CODING CAPABILITIES after Girls Coding Day.

Mark only one oval per row.

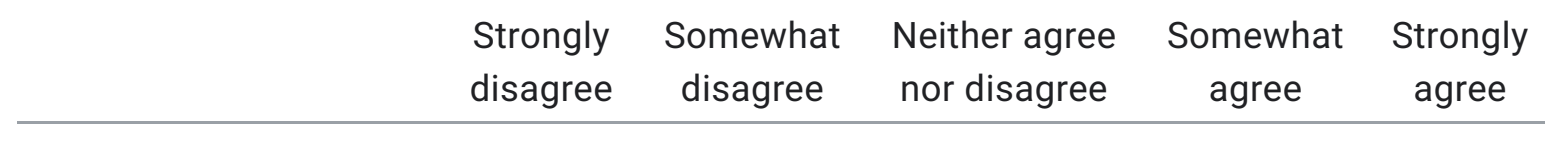

I could build a website if I had a lot of time.

I could build a website once someone else helped me to get
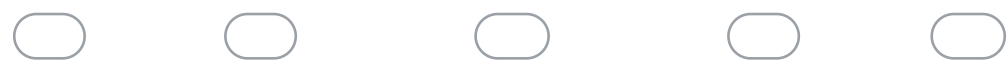
started.

I could build a website if I could call someone for help if I got stuck.
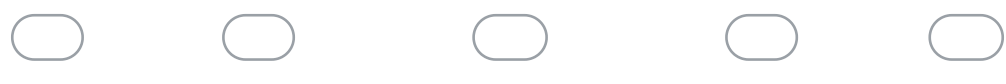

I could build a website if I had only the language reference manual for help.

I could build a website if someone showed me how to solve the problem first.

I could overcome problems if I got stuck while working on a coing project. 
36. Please indicate your level of agreement with the following statements related to your CAPABILITY OF LEARNING A NEW PROGRAMMING LANGUAGE after Girls Coding Day.

Mark only one oval per row.

\begin{tabular}{l}
$\begin{array}{c}\text { Strongly } \\
\text { disagree }\end{array}$ Somewhat \\
disagree \\
I could learn a new \\
programming language \\
on my own. \\
I could learn a new \\
programming language \\
if I had a lot of time. \\
I could learn a new \\
programming language \\
because Girls Coding \\
Day helped me get \\
started. \\
\hline $\begin{array}{l}\text { I could learn a new } \\
\text { programming language } \\
\text { if I could call someone } \\
\text { for help if I got stuck. }\end{array}$
\end{tabular}


37. Please indicate your level of agreement with the following statements related to your ability to CONTINUE LEARNING computer coding after GCD.

Mark only one oval per row.

\begin{tabular}{l}
$\begin{array}{c}\text { Strongly } \\
\text { disagree }\end{array}$ disagree \\
I would be able to \\
continue learning about \\
computer coding after \\
GCD. \\
Continuing to learn \\
about computer coding \\
after GCD is entirely \\
under my control. \\
I have the resources, \\
knowledge, and ability \\
to continue learning \\
about computer coding \\
after GCD. \\
\hline $\begin{array}{l}\text { Please click strongly } \\
\text { disagree for this one. }\end{array}$
\end{tabular}


38. Please indicate your level of agreement with the following statements related to your FUTURE INTENTIONS after Girls Coding Day.

Mark only one oval per row.

\begin{tabular}{|c|c|c|c|c|c|}
\hline & $\begin{array}{l}\text { Strongly } \\
\text { disagree }\end{array}$ & $\begin{array}{l}\text { Somewhat } \\
\text { disagree }\end{array}$ & $\begin{array}{c}\text { Neither agree } \\
\text { nor disagree }\end{array}$ & $\begin{array}{l}\text { Somewhat } \\
\text { agree }\end{array}$ & $\begin{array}{c}\text { Strongly } \\
\text { agree }\end{array}$ \\
\hline $\begin{array}{l}\text { I intend to continue } \\
\text { learning computer } \\
\text { coding rather than not } \\
\text { continue learning it. }\end{array}$ & & & & & \\
\hline
\end{tabular}

If I could, I would like to continue learning about computer codinng as
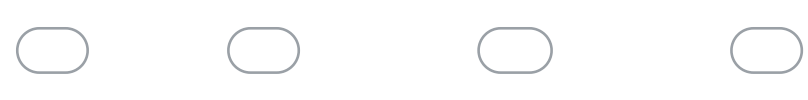
much as possible.

I would come to future Girls Coding Day events.
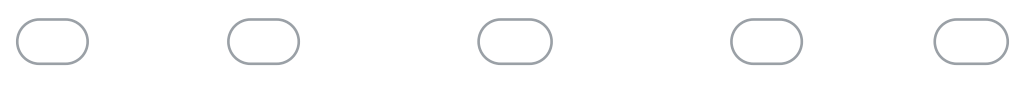

I would recommend Girls Coding Day to my friends.

Individual demographics and general feedback

39. In what year were you born? 
40. Are you...?

\section{Mark only one oval.}
$\longrightarrow$ Female
$\longrightarrow$ Male
$\longrightarrow$ Prefer not to say
Prefer to self define
Other:

41. Do you consider yourself a minority in the programmers' community?

\section{Mark only one oval.}

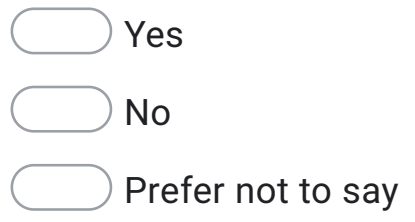

42. In your opinion, what was good about the Girls Coding Day you participated in?

43. What could be improved about Girls Coding Day?

44. Is there anything else you would like to tell us about your experience during the Girls Coding Day you participated in? 
Thank you very much

If you would like to receive a copy of our final report of our study findings, for your participation! please follow this link and provide your email address.

This content is neither created nor endorsed by Google.

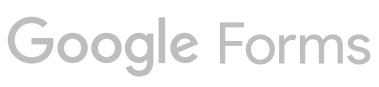

